\title{
MARX, EDUCATION AND THE POSSIBILITIES OF A FAIRER WORLD: REVIVING RADICAL POLITICAL ECONOMY THROUGH FOUCAULT
}

\author{
MARK OLSSEN \\ m.olssen@surrey.ac.uk \\ University of Surrey \\ MICHAEL A. PETERS \\ mpeters@waikato.ac.nz \\ University of Waikato
}

\begin{abstract}
Although this paper constitutes a revision of a paper originally published in 2007 [see note 1), the editors are pleased to republish this paper due to its theoretical importance for the critique of Marxism as well the interest it creates for establishing the possibility of a new political economy based upon the work of Michel Foucault. The paper documents and interrogates the contradictions between postmodernism and poststructuralism with Marxism. Starting by documenting the crisis of the Left at the start of the twenty-first century, an attempt is made to radically critique and reappraise Marxism in a direction set out by Foucault. The paper is not so much an attempt to meld Marxism and poststructuralism but rather to generate a new poststructuralist historical materialism which still has equality and fairness as its central concerns, but which goes beyond the traditional problems of Marxism based on its adherence to outmoded methodologies and theoretical modes of analysis. Echoing well known critiques of Marxist historical materialism, the paper focuses on forms of articulation drawn from the revolution in language influenced by post-modernism and by historically more recent post-quantum complexity theories.
\end{abstract}

Keywords: Marxism; the Left; political economy; poststructuralism; Michel Foucault; historical materialism; complexity; global politics; neoliberalism

It is clear, even if one admits that Marx will disappear for now, that he will reappear one day. What I wish for is not so much the defalsification and restitution of a true Marx but the unburdening and liberation of Marx in relation to party dogma, which has constrained it, touted it, and brandished it for so long (Foucault 1998, p. 458). 


\section{Introduction ${ }^{1}$}

Marxism, we are told by politicians and the popular press is dead. The Left, as a historical movement tied to the labor movement, is frozen over, caught between the collapse of actually existing communism in Eastern Europe and the triumph of global market forces. Union membership in the traditional industrial economy in the United Kingdom is dwindling as multinationals relocate offshore; even insurance, information, banking and call-centre jobs of the "new economy" are increasingly outsourced to India and other emergent economies literate in information and computing technology and English. China has joined the World Trade Organization and committed itself to a post-socialist market economy. At a time of an intensification of inequalities between regions and, perhaps more significantly, between North and South between the developed world and the developing world - the Left in Britain, the USA and most of Europe seems ideologically gutted by the Third Way preoccupation with the social market and with citizenship "responsibilities" rather than with traditional concerns of equality and advancing rights. The best offer on hand seems to be a socialization of the market and an acknowledgement of its moral limits. Neoliberalism, in the age of privatization reduces the state's role more and more to one of regulation, rather than provision or funding of public services. The US-UK neoliberal model of globalization has dominated the world economy and world politics for the last 20 years, defining the present crisis of fundamentalisms and restyling imperialism as a new age of barbarism. In this age, American-style democracy is exported alongside the ideology of "free trade." Yet many Americans have shifted their view since the Vietnam War on whether the USA is a force for good in the world or an imperialist power, and this is so despite Bush's recent election victory. Even the philosophers of ' 68 have given way to a new breed of fashion-conscious savants, who now turn their attention to extolling the virtues of liberal individualism or sneer at the last great generation of Left-Nietzscheans, such as Foucault and Derrida.

The Left has certainly been marginalized and even in the home of European socialism it seems confused and crisis-ridden. Europe itself is fighting to establish a new identity, reshaping its territory through enlargement and integration, and desperately competing with the US juggernaut of global power and the rising stars of East Asia - not only China, but also Japan, Taiwan, Hong Kong, Singapore and Korea - which seem destined to develop a trading bloc at least as powerful as that of the USA and the European Union. The traditional Left, wedded to the rise of the industrial working class, some observers have remarked, is also tied to its demise. Is the Left history? Has it simply become an academic form of analysis or does it have the seeds to reconfigure itself as an organizing force once again? 
In terms of emancipatory futures there are all sorts of oppressions to overcome; many of these oppressions have intensified in the neoliberal era. The question that Steve Brier asks is:

How do we position ourselves as a movement in relation to all the particular forms of oppression experienced by specific communities and people, defined by race, gender, nationality, sexual orientation, etc., especially at a time when no unified working-class movement exists that encompasses these communities and fights to eradicate the special injustices they face? (Brier 1999)

The question of unity becomes paramount. Against identity politics and certain forms of postmodernism we need to inquire: what is the unifying principle? Is it the concept of "class" or even an overlapping set of concepts? Brier was writing at a time that had not yet seen the neoconservative hegemony in the White House or its consolidation after the re-election of Bush for a second term. In this environment of voter fraud and corporate corruption it is difficult to see the flourishing of social democracy even though the White House wants to export American-style democracy to the world as part of its neoconservative agenda. In these circumstances is it really enough to talk of "beyond left and right" as the future of radical politics as Tony Giddens (1994) has done? Or does Alex Callinicos's (2003) Anti-Capitalist Manifesto define a way forward?

These are weighty questions that do not admit easy answers. But it is clear that even in this environment of world politics there are new lines of struggle emerging that coalesce with the old articles of faith. There are expressions of new forms of socialism that revolve around the international labor movement and invoke new imperialism struggles based on the movements of indigenous and radicalized peoples. There are active social movements, perhaps less coherent but every bit as powerful as older class-based movements, such as the anti-capitalism, anti-globalization movements, women's and feminist movements, and environmental movements. These new expressions do require engagement and re-theorizing by the Left. One obvious challenge for Marxism and the Left more generally is its engagement with Islam and the enslavement of women.

There is also a host of struggles around the socialization of the market and a question of whether this can be pursued successfully at the level beyond the state. Indeed, as many theorists have asserted, the future of the Left is tied up with the future of world democracy and with the development of left media cultures and centers. Part of the success of the Right has been its ability to privatize thinking and media, moving beyond the academy to set up dozens of new think tanks, private consultancies, and media centers that propagate partisan "news" or lobby and influence government departments at the highest levels. 


\section{Marx's Radical Political Economy}

This essay seeks to ask to what extent Foucault can provide a different vision of radical politics to that of Marx, and then to assess the implications of this for work in education, politics and ethics. Central to Marx's model of political economy was a particular materialist inversion of the Hegelian dialectic, giving rise in Western Marxism to a particular formulation of base and superstructure.

In his Preface to A Contribution to the Critique of Political Economy (Marx 1971), (hereafter CPE) written in 1859, Karl Marx, as he says, examines "the system of bourgeois economy" and he gives a biographical account of how he first came to realize the position he adopts on the issue of the relationship of the economy to the cultural, educational, legal and political domains of society - a fundamental and stunning insight whose force has not diminished even though the sophistication of structuralist and poststructuralist arguments against the rudiments of a base/superstructure model now have to be accepted. He indicates that he had started thinking about these issues in 1842 and returned to a fresh examination of Hegelian philosophy of law in order to rethink the origins of legal relations and political forms. As his massive bibliographical studies across several languages led him to conclude legal relations and political forms can not be understood by themselves or as a product of the development of the human mind but only in "the material conditions of life," the totality of which Hegel called "civil society" and whose "anatomy" Marx argued must be sought in political economy.

In that remarkable work that took him over 17 years to bring to maturity, Marx addresses the question of the method of political economy and is clearly influenced in his construction not only by the history of political economy and especially the major figures of the eighteenth century (especially Smith and Ricardo) but also Charles Darwin from whom he takes a newly scientized view of historical evolution. Marx's view is tantamount to a form of historical naturalism, which assumes laws of historical development. Marx calls it a "materialist account of history" and Engels shortened it to "historical materialism." Thus, he argues:

Bourgeois society is the most advanced and complex historical organization of production. The categories which express its relations, and an understanding of its structure, therefore, provide an insight into the structure and the relations of production of all formerly existing social formations the ruins and component elements of which were used in the creation of bourgeois society. ${ }^{2}$

Clearly his model here is Darwin as well as Hegel. This is confirmed when later in the text he argues: "The anatomy of man is a key to the anatomy of the ape." Marx claimed that all history should be thought of as the history of class-struggles over surplus-value. Engles described "being determines con- 
sciousness" as the "law of evolution in human history" equating it with Darwin's "law of evolution in organic nature." The Origin of Species ${ }^{3}$ was published in 1859 and Marx read it in 1860. Marx believed that Darwin's book "contains the basis in natural history for our views." In 1861 in a letter to Ferdinand Lassalle Marx wrote:

Darwin's book is very important and serves me as a model for the class struggle in history... Despite all deficiencies, not only is the death-blow dealt for the first time here to 'teleology' in the natural sciences, but its rational basis is empirically explained (Marx \& Engles, 1965, p. 123).

There is an oft quoted story that Marx sought permission to dedicate Das Kapital to Charles Darwin who declined the offer but this now seems suspect. ${ }^{4}$

Naturalism is the tendency to look upon the material universe as the only reality and to reduce all laws to uniformities in nature. To this end it denies the dualism of spirit and matter regarding the social and cultural as manifestations of matter that are governed by its laws. Naturalism, as Quine has suggested, is the position that there is no higher tribunal for truth than natural science itself; scientific method alone must judge the claims of science and there is no room for metaphysics or first philosophy. Naturalism is in this sense derived from materialism or pragmatism. Historical materialism explains changes in human history through material factors, for Marx, economic and technological. Where Marx is both a historical materialist and naturalist, Foucault is the former (although as we shall see he places no particular priority on the economic) but also firmly anti-naturalist when it come to the market as we will see in more detail in later sections. Naturalism, like empiricism and older forms of materialism which seek to represent the real or nature outside of discourse and independent of historicity fail to adequately recognize the contingent dimension of knowledge. For Foucault, knowledge, like the human subject is always already social and attempts to establish a foundation in nature to anchor knowledge or the operations of institutions independently of history are not possible.

For Foucault, also, the Marxist conception of relations between economy and superstructures were problematic. In the Marxist conception of historical materialism, educational, legal, political institutions, as well as ideologies and discourses, are represented as part of the superstructure of society which is split from material practices of the economic foundation or base, and are determined by it. In the same way, the mental operations of consciousness are represented as determined by the material base of society. As Marx (1971, pp. 20-21) expresses the point:

In the social production which men carry on they enter into definite relations that are indispensable and independent of their will; these relations of production correspond to a definite stage of develop- 
ment of their material powers of production. The sum total of these relations of production constitutes the economic structure of society - the real foundation, on which rise legal and political superstructures and to which correspond definite forms of social consciousness. The mode of production in material life determines the general character of the social, political and spiritual processes of life. It is not the consciousness of men that determines their existence, but on the contrary, their social existence determines their consciousness.

In the twentieth century one of the central issues addressed by western Marxists has been an attempted resolution and reconceptualization of the nature of the relation between the economic base and the cultural superstructure of society. In the classical Marxist model both the character of a society's culture and institutions, as well as the direction set for its future development are determined by the nature of the economic base, which can be defined as the mode of production at a certain stage of development (Williams 1980, p. 33). The simplest nature of this relation, as Williams (1980, p. 33) tells us, was one of "the reflection, the imitation, or the reproduction of the reality of the base in the superstructure in a more or less direct way;" that is, a relation in which the economic base and specifically the forces of production constituted the ultimate cause to which the social, legal and political framework of the society can be traced back.

In the attempt to reformulate Marxism in the twentieth century the economic determinist conception is challenged by those who see Marxism as granting rather more "independence" or "autonomy" to the superstructures of society. Hence a "dialectical" notion of the relation was stressed suggesting a relation of reciprocal influence. It was argued that, although the base conditions and affects the superstructure, it is in turn conditioned and affected by it. In all cases, however, in order to remain as Marxists, the ultimate priority of the economic base as the causal determinant of the social character of a society was safeguarded by maintaining that the economic factor is "determining in the last instance." Hence, it was maintained that the superstructure had only a "relative autonomy," and the theory of "relative autonomy," as a shorthand designation of the base-superstructure relation, became a central concept of twentieth century Marxism.

All of the Marxist studies on different aspects of education reflected the problematic determinism of the relations between the economy and the various cultural and ideological aspects of the society. If we consider the application of a particular case of Marx's base-superstructure analysis to education one important theme has been an understanding of the schooling system as a production system related to capitalism. The best known contemporary form of this kind of application is Bowles and Gintis' (1976) corres- 
pondence theory that hypothesizes a set of correspondences between work and education at all levels: a subservient workforce, an acceptance of hierarchy, and motivated by external rewards. ${ }^{5}$ In their later work they explain their original position as:

...schools prepare people for adult work rules, by socializing people to function well, and without complaint, in the hierarchical structure of the modern corporation. Schools accomplish this by what we called the correspondence principle, namely, by structuring social interactions and individual rewards to replicate the environment of the workplace (Bowles \& Gintis 2001, p. 1).

In this later work they endorse the correspondence principle as more or less correct although they also mention shortcomings of the original work. Criticisms of structural over-determination of the lives of working class kids has been explored by Paul Willis (1977) in Learning to Labour and by many others at the Centre for Contemporary Cultural Studies at the University of Birmingham who demonstrate that working class kids choose to fail through the development of a counter-culture.

\section{Foucault's Radical Political Economy}

Political economy has a much longer tradition than as used by Marx. The Greeks considered it as pertaining to the management of the household of the state, as did Jean Jacques Rousseau and Adam Smith. ${ }^{6}$

Foucault's sense of the concept must be seen in relation to his way of conceptualizing social structure as well as his opposition to Marxism. In one sense, his own conception can be viewed as a form of "new political economy." Foucault opposed both the determinism of the base-superstructure model as well as the Hegelian monistic conception of society and the Hegelian/ Darwinian conception of progressive evolution of history through the unfolding of the dialectic to the communist utopia. Rather than seek to explain all phenomena in relation to a single centre, Foucault is interested rather to advance a polymorphous conception of determination in order to reveal the play of dependencies in the social and historical process. Hence, in opposition to the themes of totalizing history as found in Hegel, Foucault (1978, p. 10) substitutes what he calls a "differentiated analysis:"

Nothing, you see, is more foreign to me than the quest for a sovereign, unique and constraining form. I do not seek to detect, starting from diverse signs, the unitary spirit of an epoch, the general form of its consciousness: something like a Weltanschauung....I have studied, one after another, ensembles of discourse; I have characterized them; I have defined the play of rules, of transformations, of thresholds, of remanences. I have established and I 
have described their clusters of relations. Whenever I have deemed it necessary I have allowed systems to proliferate.

In advocating pluralism in place of monism, Foucault believed Marxism to reflect theoretical rules inherited from its time of origins. As he says (2001a, p. 269):

Marx's economic discourse comes under the rules of formation of the scientific discourses that were peculiar to the nineteenth century...Marxist economics - through its basic concepts and the general rules of its discourse - belongs to a type of discursive formation that was defined around the time of Ricardo.

A central element of Foucault's critique of Marxism relates to the notion of "totalization." Essentially, for Foucault, Marxism was not just a "deterministic" but a "deductivistic" approach. That is, it directs attention not just to the primacy of the economy but it seeks to explain the parts of a culture as explicable and decodable parts of the whole totality or system represented as a closed system. Marxism, claims Foucault, seeks to ascertain "the principle of cohesion or the code that unlocks the system explaining the elements by deduction" (Thompson 1986, p. 106). This was the approach of Marx took from Hegel, which seeks to analyze history and society in terms of "totality," where the parts are an "expression" of the whole - hence the notion of an "expressive totality."

The dissociation between Marxism, and Foucault's own position became more apparent after Foucault's turn to genealogy and Nietzsche at the close of the 1960s. With his growing interest in genealogy, Foucault became more concerned with power and history, and the historical constitution of knowledge. In this process, there was however, no integrative principle or essence, and history was not periodized according to economic stages. If the genealogist studies history "he finds that there is 'something altogether different' behind things: not a timeless and essential secret, but the secret that they have no essence or that their essence was fabricated in a piecemeal fashion from alien forms" (Foucault 1977, p. 142)

Foucault's objection to elements of Marxism explicitly reflects his Nietzschean heritage and his belief that certain aspects of Marxism distorted the liberatory potential of the discourse.

The interest in Nietzsche and Bataille was not a way of distancing ourselves from Marxism or communism - it was the only path towards what we expected from communism (Foucault 2001, p. 249).

It was in terms of the philosophy of difference and Nietzsche's conception of multiplicities through a rejection of Platonic hierarchies that Foucault enunciates a theory of discursive formations and rejects Marxist and Hegelian 
conceptions of history. The utilization of Nietzsche signaled a rupture from Marxism in relation to a series of inter-related conceptual, theoretical and methodological precepts, including power, knowledge and truth, the subject, and the nature of historical change and determination.

Nietzsche focused on power in an altogether different way to Marx. In "Prison Talk," Foucault (1980a, p. 47) states:

It was Nietzsche who specified the power relation as the general focus, shall we say, of philosophical discourse - whereas for Marx it was the productive relation. Nietzsche is the philosopher of power, a philosopher who managed to think of power without having to confine himself within a political theory in order to do so.

Power, for Nietzsche, was conceived as a relation of forces within an analytics of power/knowledge/truth, which became important for Foucault to understand in the later 1960s after the publication of The Archaeology of Knowledge and his growing friendship with the Parisian Nietzschean Gilles Deleuze. Foucault accredits Nietzsche as the source of his interest in the question of truth and its relation to power. As he states, in "Truth and Power" (Foucault, 1980, p. 133), "The political question...is not, error, illusion, alienated consciousness or ideology, it is truth itself. Hence, the importance of Nietzsche." Nietzsche's importance to Foucault can be seen as "correcting" the Marxism developed after Marx, especially in relation to the linkage between power-knowledge-truth, and the functioning of knowledge as an instrument of power. As Alan Schrift (1995, p. 40) notes, Nietzsche's influence drew attention away from "substances, subjects and things, and focused attention instead on the relations between these substantives." In a related way, Foucault "draws our attention away from the substantive notion of power and directs our attention instead to the multifarious ways that power operates through the social order" $(1995$, p. 40). For Nietzsche, such relations were relations of forces. Foucault thus focused on new relations as the relations of forces that existed and interacted within social systems as social practices. These were forces of repression and production that characterized the disciplinary society; forces that enable and block; subjugate and realize, and normalize and resist. In this model, power is not a thing, but a process, a becoming.

Foucault rejects Marxist models of a determining economic base and a determined superstructure as well as refinements based on conceptions of totality by Marx's twentieth century successors. Foucault is not interested in accounting for the practices of the social structure solely in terms of a model of economic determination. Although, like Althusser, he utilizes a model of complex and multiple causation and determination within the social structure, the specific elements and mechanisms of such processes, as elaborated by Foucault, differ in important, indeed crucial, respects. In Foucault's concep- 
tion of social structure, explaining the relations between discursive formations and non-discursive domains (institutions, political events, economic practices and processes) is recognized as the ultimate objective. As he formulates it in The Archaeology of Knowledge (1972), for archaeology, in comparison to Marxism:

The rapprochements are not intended to uncover great cultural continuities, nor to isolate mechanisms of causality ... nor does it seek to rediscover what is expressed in them ... it tries to determine how the rules of formation that govern it . . . may be linked to non-discursive systems: it seeks to define specific forms of articulation (Foucault, 1972, p. 162).

Unlike Marxists, he sees no one set of factors as necessarily directing human destiny. Rather, the forms of articulation and determination may differ in relation to the relative importance of different non-discursive (material) factors in terms of both place and time. In the shift from a purely archaeological to a genealogical mode of enquiry, Foucault's concern with the relation between discursive and non-discursive domains is given a more historical and dynamic formulation, although, the concern with synchronic analysis is not abandoned. Throughout, however, as Mark Poster (1984, pp. 39-40) explains, Foucault's central aim is to provide a version of critical theory in which the economic base is not the totalizing centre of the social formation, whereby Hegel's evolutionary model of history is replaced by Nietzsche's concept of genealogy, and where causes and connections to an imputed centre or foundation are rejected in favor of exposing the contingency and transitory nature of existing social practices. In Poster's (1984, pp. 39-40) view, this presents us with a crucial decision. In comparing Foucault and Althusser, he maintains that "the theoretical choice offered by these two theorists is dramatic and urgent. In my opinion Foucault's position in the present context is more valuable as an interpretative strategy. . . Foucault's position opens up critical theory more than Althusser's both to the changing social formation and to the social locations where contestation actually occurs." While having a generally historicized view of the nature and development of knowledge, Foucault rejects the possibility of any "absolute" or "transcendental" conception of truth "outside of history" as well as of any conception of "objective" or "necessary" interests which could provide a necessary "Archimedean point" to ground either knowledge, morality or politics. Read in this way, historical materialism does not prioritize the economy in any necessary or universal sense, but is about the systematic character of society and how it might change. It is about the processes of change internal to social systems. It holds that societies are to varying extents integrated systematically through their material practices and discursive coherences, and break down and change as the component elements of the system change. ${ }^{8}$ 


\section{Governmentality Studies}

Based upon this general social ontology Foucault utilizes the notion of "governmentality" as the basis of his "new" conception of political economy. The working premise of governmentality studies is based on Foucault's insight and analysis of the modern regime of power in which power characteristically operates internally or subjectively in terms of a logic of "self-improvement" that demands the freedom of the individual. Governmentality is the key concept that links Foucault genealogy of the subject with his interest in political rationalities, i.e., between the government of the State and the government of the self, and in so doing "solves" the problem of agency (liberal political economy) versus structure (Marxist political economy).

Foucault's overriding interest was not in "knowledge as ideology," as Marxists would have it, where bourgeois knowledge, say, modern liberal economics was seen as false knowledge or bad science. Nor was he interested in "knowledge as theory" as classical liberalism has constructed disinterested knowledge, based on inherited distinctions from the Greeks, including Platonic epistemology and endorsed by the Kantian separation of schema/content that distinguishes the analytic enterprise. Rather Foucault examined practices of knowledge produced through the relations of power. ${ }^{9}$ He examined how these practices, then, were used to augment and refine the efficacy and instrumentality of power in its exercise over both individuals and populations, and also in large measure helped to shape the constitution of subjectivity. Fundamental to his governmentality studies was the understanding that Western society professed to be based on principles of liberty and the Rule of Law and said to derive the legitimation of the State from political philosophies that elucidated these very principles. Yet as a matter of historical fact, Western society employed technologies of power that operated on forms of disciplinary order or were based on biopolitical techniques that bypassed the law and its freedoms altogether. As Colin Gordon (2001, p. xxvi) puts it so starkly: Foucault embraced Nietzsche as the thinker "who transforms Western philosophy by rejecting its founding disjunction of power and knowledge as myth." By this he means that the rationalities of Western politics, from the time of the Greeks, had incorporated techniques of power specific to Western practices of government, first, in the expert knowledges of the Greek tyrant and, second, in the concept of pastoral power that characterized ecclesiastical government.

It is in this vein that Foucault examines government as a practice and problematic that first emerges in the sixteenth century and is characterized by the insertion of economy into political practice. Foucault (2001, p. 201) explores the problem of government as it "explodes in the sixteenth century" after the collapse of feudalism and the establishment of new territorial States. 
Government emerges at this time as a general problem dispersed across quite different questions: Foucault mentions specifically the Stoic revival that focused on the government of oneself; the government of souls elaborated in Catholic and Protestant pastoral doctrine; the government of children and the problematic of pedagogy; and, last but not least, the government of the State by the prince. Through the reception of Machiavelli's The Prince in the sixteenth century and its rediscovery in the nineteenth century, there emerges a literature that sought to replace the power of the prince with the art of government understood in terms of the government of the family, based on the central concept of "economy." The introduction of economy into political practice is for Foucault the essential issue in the establishment of the art of government. As he points out, the problem is still posed for Rousseau, in the mid- $18^{\text {th }}$ century, in the same terms - the government of the State is modeled on the management by the head of the family over his family, household and its assets.

It is in the late sixteenth century, then, that the art of government receives its first formulation as "reason of state" that emphasizes a specific rationality intrinsic to the nature of the state, based on principles no longer philosophical and transcendent, or theological and divine, but rather centered on the problem of population. This became a science of government conceived of outside the juridical framework of sovereignty characteristic of the feudal territory and firmly focused on the problem of population based on the modern concept which enabled "the creation of new orders of knowledge, new objects of intervention, new forms of subjectivity and ... new state forms" (Curtis, 2002, p. 2). It is this political-statistical concept of population that provided the means by which the government of the state came to involve individualization and totalization, and, thus, married Christian pastoral care with sovereign political authority. The new rationality of "reason of state" focused on the couplet population-wealth as an object of rule, providing conditions for the emergence of political economy as a form of analysis. Foucault investigated the techniques of police science and a new bio-politics,

which tends to treat the 'population' as a mass of living and coexisting beings, which evidence biological traits and particular kinds of pathologies and which, in consequence, give rise to specific knowledges and techniques (Foucault 1989, p. 106, cited in Curtis, 2002).

As Foucault (2001) comments in "The Political Technology of Individuals," the "rise and development of our modern political rationality" as "reason of state," that is, as a specific rationality intrinsic to the state, is formulated through "a new relation between politics as a practice and as knowledge" (p. 407), involving specific political knowledge or "political arithmetic" (statistics); "new relationships between politics and history," such that political knowl- 
edge helped to strengthen the state and at the same time ushered in an era of politics based on "an irreducible multiplicity of states struggling and competing in a limited history" (p. 409); and, finally, a new relationship between the individual and the state, where "the individual becomes pertinent for the state insofar as he can do something for the strength of the state" (p. 409). In analyzing the works of von Justi, Foucault infers that the true object of the police becomes, at the end of the eighteenth century, the population; or, in other words, the state has essentially to take care of men as a population. It wields its power over living beings, and its politics, therefore has to be a biopolitics (p. 416).

Foucault's lectures on governmentality were first delivered in a course he gave at the Collège de France, entitled Sécurité, Territoire, Population, during the 1977-78 academic year. While the essays "Governmentality" and "Questions of Method" were published in 1978 and 1980, respectively, and translated into English in the collection The Foucault Effect: Studies in Governmentality (Burchell et al., 1991), it is only very recently that the course itself has been transcribed from original tapes and published for the first time (Foucault, 2004a), along with the sequel Naissance de la biopolitique: Cours au Collège de France, 1978-1979 (Foucault, 2004b). ${ }^{10}$ The governmentality literature in English, roughly speaking, dates from the 1991 collection and has now grown quite substantially (see, for example, Miller and Rose, 1990; Barry et al., 1996; Dean, 1999; Rose, 1999). ${ }^{11}$ As a number of scholars have pointed out Foucault relied on a group of researchers to help him in his endeavors: François Ewald, Pasquale Pasquino, Daniel Defert, Giovanna Procacci, Jacques Donzelot, on governmentality; François Ewald, Catherine Mevel, Éliane Allo, Nathanie Coppinger and Pasquale Pasquino, François Delaporte and Anne-Marie Moulin, on the birth of biopolitics. These researchers working with Foucault in the late 1970s constitute the first generation of governmentality studies scholars and many have gone on to publish significant works too numerous to list here. In the field of education as yet not a great deal has focused specifically on governmentality. ${ }^{12}$

Gordon (2001, p. xxiii) indicates three shifts that took place in Foucault's thinking: a shift from a focus on "specialized practices and knowledges of the individual person" "to the exercise of political sovereignty exercised by the state over an entire population;" the study of government as a practice informed and enabled by a specific rationality or succession of different rationalities; and, the understanding that liberalism, by contrast with socialism, possessed a distinctive concept and rationale for the activity of governing. Liberalism and neoliberalism, then, for Foucault represented distinctive innovations in the history of governmental rationality. In his governmentality studies Foucault focused on the introduction of economy into the practice of politics and in a turn to the contemporary scene studied two examples: 
German liberalism during the period 1948-62, with an emphasis on the Ordoliberalism of the Freiburg School, and American neoliberalism of the Chicago School. Foucault's critical reading of German neoliberalism and the emergence of the "social market" has significance not only for understanding the historical development of an economic constitution and formulation of "social policy" (and the role of education policy within it), but also the development of the European social model, more generally, and the continued relevance for Third Way politics of the "social market economy."

\section{Neoliberalism and the Birth of Biopolitics}

Naissance de la biopolitique (Foucault, 2004b) consists of thirteen lectures delivered by Foucault at the Collège de France (10 January- $4^{\text {th }}$ April, 1979). It is helpful to see this course in the series of thirteen courses he gave from 1970 to 1984 . The first five courses reflected his early work on knowledge in the human sciences, concerning punishment, penal and psychiatric institutions: "La Volonté de savoir" (1970-71), "Théories et Institutions pénales" (197172), "La Société punitive" (1972-73), "Le Pouvoir psychiatrique" (1973-74), "Les Anormaux" (1974-75). The remaining eight courses focused squarely on governmentality studies, with a clear emphasis also on the problematic (and hermeneutics) of the subject and the relation between subjectivity and truth: "It faut défender la société" (1975-76), "Securité, Territoire, Population" (1977-78), "Naissance de la biopolitique" (1978-79), "Du gouvernement des vivants" (1979-80), "Subjectivité et Vérité" (1980-81), "L'Herméneutique du subjet" (1981-82), "Le Gouvernement de soi et des autres" (1982-83), "Le Gouvernement de soi et des autres: le courage de la verite" (1983-84). Even from this list of courses is become readily apparent that the question of government concerns Foucault for the last decade of his life and that for his governmentality studies, politics were inseparable in its modern forms both from biology - biopower and the government of the living - and truth and subjectivity. It is important to note that these same concerns in one form or another enter into Foucault's formulations in Naissance de la biopolitique. ${ }^{13}$

The Ordoliberalen ${ }^{14}$ comprised a group of jurists and economists in the years 1928-1930 who published in the yearbook Ordo. Amongst their numbers were included William Röpke, Walter Eucken, Franz Böhm, Alexander Rüstow, Alfred Müller-Armack and others. Preaching the slogan that "inequality is equal for all" they devised a social market economy influencing the shaping of West German economic policy as it developed after the war. Foucault refers to these Ordoliberalen as the "Freiberg School" who had some affinities (of time and place) with the Frankfurt School but were of a very different political persuasion. While they held that Nazism was a consequence of the absence of liberalism, they did not see liberalism as a 
doctrine based upon the natural freedom of the individual that will develop by itself of its own volition. In fact, for the "Freiberg School" the market economy was not an autonomous, or naturally self-regulating entity at all. As a consequence, their conception of the market and of the role of competition, says Foucault, is radically anti-naturalistic. Rather than the market being a natural arena which the state must refrain from interfering with, it is rather constituted and kept going by the state's political machine. Similarly, competition is not a natural fact which emerges spontaneously from human social intercourse, as a result of human nature, but must be engineered by the state.

As a consequence of this, the traditional distinction between a sphere of natural liberty and a sphere of government intervention no longer holds, for the market order and competition are engineered by the practices of government. Both the state and the market are on this conception artificial and both presuppose each other. In Foucault's view such a conception means that the principle of laissez-faire, which can be traced back to a distinction between culture (the artificial state) and nature (the self-regulating market), no longer holds. For the Ordoliberalen, the history of capitalism is an institutional, non-natural, history. Capitalism is a particular contingent apparatus by which economic processes and institutional frameworks are articulated. Not only is there no "logic of capital" in this model, but the Ordoliberalen held that the dysfunctions of capitalism could only be corrected by political-institutional interventions which they saw as contingent historical phenomena. What this means, says Foucault, is that the Ordoliberalen support the active creation of the social conditions for an effective competitive market order. Education thus becomes pivotal in this constructivism. Not only must government block and prevent anti-competitive practices, but it must fine-tune and actively promote competition in both the economy and in areas where the market mechanism is traditionally least prone to operate. One policy to this effect was to "universalize the entrepreneurial form" (Lemke, 2001, p. 195) through the promotion of an enterprise culture, premised, as Foucault put it in a lecture given on $14^{\text {th }}$ February 1979, on "equal inequality for all" (Lemke, 2001, p. 195). The goal here was to increase competitive forms throughout society so that social and work relations in general assume the market form i.e., exhibit competition, obey laws of supply and demand. In the writings of Rüstow, this was called "vital policy" ("Vitalpolitik") which described policies geared to reconstructing the moral and cultural order to promote and reward entrepreneurial behavior, opposing bureaucratic initiatives which stifle the market mechanism. To achieve such goals, the Ordoliberalen also advocated the redefining of law and of juridical institutions so that they could function to correct the market mechanism and discipline non-entrepreneurial behavior within an institutional structure in accordance with, and supported by, the 
law. In this sense, the Ordoliberalen were not simply anti-naturalist, but constructivist.

In his analysis of neoliberalism, Foucault also directs his attention to the Chicago School of Human Capital theorists in America, focusing particularly on the works of Gary Becker. These neoliberals also opposed state interventionism when it was bureaucratic and supported it when it fostered and protected economic liberty. For Human Capital theorists the concern was the uncontrolled growth of the bureaucratic apparatus as a threat to the freedom of the individual. Foucault sees the major distinction between the German and US neoliberals existing in the fact that in the US neoliberalism was much less a political crusade as it was in Germany or France, for in the US the critique was centrally directed against state interventionism and aimed to challenge the growth of the state apparatus. In his lecture of March 28, 1979, Foucault discusses Hayek and von Mises (whom he labels as the "intermediaries of US neoliberalism"), Simons, Schultz, Stigler and Gary Becker, whom he says is the most radical exponent in the US. The US neoliberals saw the Ordoliberalen as representing the political as being above and outside the market but constantly intervening to correct its bureaucratic dislocations. From their viewpoint, they wanted to extend the market across into the social arena and political arenas, thus collapsing the distinction between the economic, social and political in what constitutes a marketization of the state.

As Foucault sees HCT, it is concerned with the problem of labor in economic theory. While classical political economy claimed that the production of goods depended upon real estate, capital, and labor, neo-liberals held that only real estate and capital are treated appropriately by the classical theory, and that labor needs greater illumination as an active, rather than as a passive, factor in production. In this sense neoliberals concurred with Marx that classical political economy had forgotten labor and thereby they misrepresent the process of production. In order to correct this deficiency, neoliberals theorize the role and importance of labor in terms of a model of human capital. In essence their theory starts with the human individual in terms of a classification of skills, knowledge and ability. Although, unlike other forms of capital, it cannot be separated from the individual who owns these resources, they nevertheless constitute resources which can be sold in a market. Becker distinguishes two central aspects to such human capital: (1) inborn, physical and genetic dispositions, and (2) education, nutrition, training and emotional health. In this model, each person is now an autonomous entrepreneur responsible ontologically for their own selves and their own progress and position. Individuals have full responsibility over their investment decisions and must aim to produce a surplus value. As Foucault puts it in his March 14, 1979 lecture, noting the educational implication, they are "entrepreneurs of themselves." 
Graham Burchell (1996, pp. 23-24) has noted the core distinction between classical and neoliberalism. Whereas for liberalism the basis of government conduct is in terms of "natural, private-interest-motivated conduct of free, market exchanging individuals," for neoliberalism "the rational principle for regulating and limiting governmental activity must be determined by reference to artificially arranged or contrived forms of free, entrepreneurial and competitive conduct of economic-rational individuals." This means that for neoliberal perspectives, the end goals of freedom, choice, consumer sovereignty, competition and individual initiative, as well as those of compliance and obedience, must be constructions of the state acting now in its positive role through the development of the techniques of auditing, accounting and management. It is these techniques, as Barry, Osborne and Rose (1996, p. 14) put it:

[that] enable the marketplace for services to be established as 'autonomous' from central control. Neo-liberalism, in these terms, involves less a retreat from governmental 'intervention' than a reinscription of the techniques and forms of expertise required for the exercise of government.

Notwithstanding this rather crucial difference between the two forms of liberalism, the common element expresses a distinctive concern. For both classical liberalism as well as neoliberalism, what defines this concern is a common orientation concerning "the limits of government in relation to the market" (Burchell, 1996, p. 22).

In addition to a common priority concerning the scope of the market, both classical liberalism and neoliberalism share common views concerning the nature of the individual, as rational self-interested subjects. In this perspective the individual is presented as a rational optimizer and the best judge of his/her own interests and needs. Being rational was to follow a systematic program of action underpinned and structured according to rules. The rules were rendered coherent and permissible in relation to the "interests" of the individual.

In summary, then, central to neoliberals such as the Ordoliberalen and Public Choice theorists, the state actively constructs the market. Far from existing within a protected and limited space, market relations now extend to cover all forms of voluntary behavior amongst individuals. Rather than absenting itself from interfering in the private or market spheres of society, Foucauldian political economy points out that in the global economic era neoliberalism becomes a new authoritarian discourse of state management and control. Rather than being a form of political bureaucracy, which Weber (1921) saw as the supreme form of modernist rationality, neoliberalism constitutes a new and more advanced technology of control. It is both a substantive political doctrine of control and a self-driving technology of operations. 
It incorporates both more flexible and more devolved governmental steering mechanisms than does bureaucracy. If, for Weber, bureaucracy constituted large scale organization comprising a hierarchy of offices and lines of control, enabling efficiency, predictability, calculability and technical control, then neoliberalism, while incorporating these factors, goes beyond them to enable an extension of control in more devolved forms and in more flexible systems. This enables the function of control to be differentiated from the function of operations, or to use Osborne and Gaebler's (1992) metaphor, "steering" from "rowing." It points to a more effective means of social engineering and control than classical bureaucracy, scientific management, or the Fordist assembly line. Its overall rationale is to measure the costs of, and place a monetary or market value on, all forms of human activity in order to render it controllable. It extends the market mechanism from the economic to the political to the social. Market exchanges now encapsulate all forms of voluntary behavior amongst individuals. ${ }^{15}$

\section{Towards a Possible Foucauldian Politics}

If Foucault is critical of neoliberalism as being a new form of superstructural sociology, in many ways highlighting a new operating model of capitalism in a global era, his model of political economy also supports, and has affinities to, a particular approach to economics and politics that can be represented to tie in closely with "regulation school" approaches developed by writers like Michel Aglietta, Hughes Bertrand, Robert Boyer, Alan Lipietz and Jacques Mistral. Aglietta has commented directly on Foucault's contribution in his conversations with Francois Dosse (1997, p. 291) where he describes Foucault's importance as being "because he raised questions about institutions and gave answers." Furthermore, as Dosse explains, Aglietta was especially influenced by Foucault's:

concern for micropowers, his shift from the centre to the peripheral, his pluralization of a polymorphous power that corresponded to the regulationists' desire to reach intermediary institutional bodies. Moreover, Foucault had made it possible to take some distance from 'the fundamental conception of Marxism' and to understand that this smooth growth curve depended on a system of conciliation and a concentration of interests. Until then, the antagonoism between capitalists and workers was considered irreconciliable. (Dosse, 1997, p. 291)

The "regulationists" rendered structuralism dynamic and bought microstructures and human beings back into the orbit of the analysis. As well as incorporating much from the tradition of Marxism, they were also influenced by Keynesian economics through the consideration of real demand, and by 
arguing for a consideration of money as an institution, and work as a relationship rather than a market. Robert Boyer (1986) and Alain Lipietz (1983, 1995) also accepted a "broad church" conception of the regulationist approach, distancing themselves from the more specific variations that also developed (see Dosse, 290-294).

Central to the regulation school approach was its rejection of the market order as a self-regulating entity, and its "openness to social and historical elements" (Dosse, 1997, p. 292). This presents the future as an always existing constellation of dangers, and has enormous implications for ethics and education. As with Foucault there was an appropriation of some features of Marxism (especially Althusserianism), a conception of holism/particularism; an appreciation that the laws governing economic tendencies are historically contingent, and a concern for institutional forms of power as they arose from divergent conflicts or from market processes. The emphasis on historicity meant that there was no recognition of predetermined universal categories or systems such as forces of production, in preference for a recognition of the historical variability of other economic institutions, such as money or markets. What resulted was a reinterpretation of economic phenomena in terms of dynamic schemas as responding to dynamic mechanisms. Individual behaviors and identities were forged out of complex wholes, hence individual behaviors and subjects were viewed in ways that did not embody methodological individualism, enabling a reintroduction of individuals in relation to groups and social categories.

\section{From Governmentality to the Hermeneutics of the Self as Education}

The distinctiveness of Foucault's emerging problematic of governmentality, formulated in the years 1978-79, also developed in a series of subsequent themes as "the government of the living," "subjectivity and truth," and "the government of self and others." These themes were also of relevance to education as a practice of struggle and engagement, and as such help us to understand the differences between a Foucauldian political economy of praxis, and that of Marxism. Of particular significance here are the themes on the problematic (and hermeneutics) of the subject and the relation between subjectivity and truth. These indeed signify a different relation between individual and collective in Foucault's work, compared to Marxism or Hegelianism. Although the individual subject is a product of social conditioning, they are always "free standing" in the sense they are never completely confined or defined by the determining structures from which they derive. Every convergence around culture or conditioning is also characterized by difference on the grounds that experience within space and time is itself both individuating and educative. Thus, while each individual is the product of class and 
culture each also has a situated and dated uniqueness. As Jane Bennett (1996, p. 660) states, citing Foucault:

There is no escaping a regime of power, but this does not mean that subjectivation is simply subjection, for there is always the possibility of 'practices of liberation, of freedom, as in Antiquity, starting of course from a certain number of rules, styles and conventions that are found in the culture.' (Bennett is citing Foucault, 1989a, p. 313)

This theorisation of the individual within the whole as something which both reflects and yet exceeds it, is distinctive of Foucault correction to Marxism, forcefully expressed in theoretical terms in works such as The Archaeology of Knowledge (1972).

Another difference from Marxism, springing from the rejection of Hegelian conceptions of a unilinear and progressive history is Foucault's distain for utopian ideas which aim for the realization of a perfected or harmonious future society. To aim for a specific ordered ideal written "only on paper" as something that could exist harbors dangers associated with both "radical and global" forms of theorizing. Foucault (1984a, p. 46) echoes liberal concerns with utopian engineering when he states that:

we know from experience that the claims to escape from the system of contemporary reality so as to produce the overall programs of another society, of another way of thinking, another culture, another vision of the world, has led only to the return of the most dangerous traditions.

Foucault puts more emphasis on local struggle and resistance on the basis that existing historical discursive systems (such as those concerning liberty, rights, democracy, etc) which can be seen already - in the present horizon to harbor a "repressed" or "sedimented" utopian vision. Such existing discourses which always operate in local sites can be seen to constitute the complex outcome of struggles in history. And it is in this sense that local struggles can be seen as the basis of revolutionary activity. For Foucault, the revolution as Marxism conceived it as a single historical act of violence and transformation fails theoretically to be plausible in a global age because it can only be taken seriously within a unilinear and utopian frame of reference. What must be asked anew is how would such an idea of revolution can be conceived, planned for, and organized in an age which is both global and local. The notion of simultaneous and coordinated action across national contexts is no longer feasible in a global and "virtual" world. Indeed, to envisage a total sudden reconstruction or reordering of society given the dispersed digital character of financial and intelligence networks in advanced industrial nations boggles the mind. Hence, for Foucault, in a world which is 
both global and local the drive for change must take the form of resistance and struggle in specific sites, utilizing complex technologies and intellectual tools.

In addition to operating in specific sites, Foucault also emphasizes the tasks of the "specific intellectual" as "sapping power" rather than "proposing alternative visions" or "telling people what to do." A critical interrogation of power is thus central as the basis of a critical education. As Foucault (1977b, p. 208) explains to Gilles Deleuze:

The intellectual's role is no longer to place himself 'somewhat ahead and to the side' in order to express the stifled truth of the collectivity; rather, it is to struggle against the forms of power that transform him into its object and instrument in the sphere of 'knowledge,' 'truth,' 'consciousness,' and 'discourse.' In this sense theory does not express, translate, or serve to apply practice: it is practice. But it is local and regional ... and not totalizing. This is a struggle against power, a struggle aimed at revealing and undermining power where it is most invisible and insidious. It is not to 'awaken consciousness' that we struggle... but to sap power, to take power; it is an activity conducted alongside those who struggle for power, and not their illumination from a safe distance. A 'theory' is the regional system of this struggle.

The impossibility of a discrete and total revolution also suggests the fact that on some issues and for some groups the revolution as Marxists conceived it might be considered in some senses as having already occurred. The theoretical task becomes in identifying those specific aspects or dimensions still not corrected such as climate change, the unjustified profits of many large multinationals, global inequality, the disadvantages of race, class, disability and gender both within societies and globally. The normative standards constitutive of a good for mankind are already present, in some cases manifest, in some repressed, within the existing horizon based upon what is necessary for both collective and individual survival. This is to say that complex historically generated discourses on such things as rights, equality, democracy and education for survival, already exist, and constitute the repositories of knowledge to become the curriculum for education for global citizenship in the future. Such a global polis is a thin, or de-centered community, rather than a unified mutuality in Hegel's sense. It is motivated not by a model of the truth, but more pragmatically, by a normative conception of survival characterized by a common integrity and flourishing but which may take many different forms. Foucault's fellow Nietzschean thinker, and lifelong inspiration, Georges Bataille, theorized the importance of survival as the pragmatic source and guide of ethics and education. For Bataille, like Nietzsche, the struggle for survival represents a specifically non-moral yearning once 
"God is dead," a goal that stretches out before one, as Bataille (2004, p. xviii) puts it, "independently of moral goals or of serving God," and yet paradoxically itself becomes interpreted as a moral obligation, imposing an object "that surpasses all others in value" (xvii) and translating as a "demand for definite acts" (xvii). As in a complex global world people are interdependent, individual and collective goals are intertwined: the well-being of one is inseparable from the well-being of all. John Dewey's model of problem solving for survival resonates a similar approach.

It is well known that Marx never theorized the nature of existence in the communist utopia in any detail, and he may well have lacked the tools for such an analysis, ${ }^{16}$ but there is reason to believe that he held intuitively to a similar conception to Foucault. Foucault sees difference as manifesting itself, necessarily, within unity, the latter which is always precarious, always changing and never completely predictable. Just for instance, as "Britishness" defines a common attribute between a group of people, so within the group, and simultaneous or identical with it, there are a myriad of differences, pertaining to appearance, gender, age, or what have you. In this sense commonness and difference are co-present features of any phenomena. Within the existing horizon of survival, there are many legitimate yet different ways to live. It is in this sense also that in place of unilinear conceptions of change and causality, Foucault's model of historical materialism is consistent with twentieth century conceptions of complexity theory. New realities, both physical and social, manifest themselves as emergent phenomena. While there is no necessary equilibrium which produces "happy endings" or "selfregulated markets," within limits we can understand the affects that particular combinations, alliances and choices entail. Understanding possible affects of combinations, and alliances, is indeed the task of education and of ethics. To understand education as concerned with a theory of affects, is of course to draw off Deleuze, as well as Spinoza and Nietzsche. ${ }^{17}$ Yet it is an extension which we think (or hope) Foucault might approve. ${ }^{18}$ Certainly it extends his thought in a way which brings out the important differences to Marxism, in a way related to how ethics and education would be conceived to have a role in the new era which is both global and national and which confronts a world that still awaits to be transformed.

The different way individual and collective are related in Foucault compared to Marxism indeed suggests a new order of ethics. In his later books, The Use of Pleasure and The Care of the Self, as Jane Bennett (1996, p. 655) explains, Foucault considers ethics as both a "code of morality" and in relation to "subjectivation." As a "code morality," ethics relates to justified moral precepts and rules. Christianity comprised one set of these, yet today, the new demands of survival, centering on issues like climate change and the health of populations, presents a different set of precepts to guide action. In 
addition, however, such rules will not dictate or define conduct for each individual for every situation. While the tasks and requirements of survival will dictate some general, although historically specific, precepts and "rules," different contingent imperatives at different times and places will also operate, so the individuals' mode of ethical comportment will also reflect decisions, choices and commitments which only he/she can decide in particular situations. For Foucault, as for poststructuralism in general, every action, like every statement, has a novel aspect, a situated and dated uniqueness, whereby ethical decisions and actions assume great importance for society and for the groups and individuals that comprise it. In this sense, as Bennett (1996, p. 655) explains, "Foucault finds 'code morality' insufficient." She cites Foucault (1985, p. 28):

In short, for an action to be 'moral,' it must not be reducible to an act or a series of acts conforming to a rule, or a value. There is no moral conduct that does not [also] call for forming of oneself as an ethical subject; and no forming of the ethical subject without 'modes of subjectivation' and an 'ascetics' or 'practices of the self' that support them.

One dimension of Foucault's writings on ethics that assumes importance for education today relates to global activism. This is related to the propensity or preparedness of groups and individuals to speak out, take a stand, or to join together to protest. Foucault, in his own life, manifested a constant preparedness and concern with many causes including the rights of prisoners, of lawyers who defended radical groups, and of the poor. Hence, he voiced concern for the rights of those on the high seas, against piracy, where he speaks of "human rights" to "confront governments" which are beyond the limits of nationality. ${ }^{19}$ As he puts it (Foucault, 2001b, p. 474),

There exists an international citizenship that has its rights and its duties, and that obliges one to speak out against every abuse of power, whoever its author, whoever its victims. After all, we are all members of the community of the governed, and thereby obliged to show mutual solidarity.... It is the duty of this international citizenship to always bring the testimony of people's suffering to the eyes and ears of governments....The suffering of men must never be the silent residue of policy. It grounds an absolute right to stand up and speak to those who hold power.

Foucault's approach, as extended through concepts such as parrhésia, and contestation and resistance, also supports a model of global democracy and the role of grassroots critical social movements, which constitute a "bottom up" theory of the democratization of world order, and suggests a conception of education as instilling radical global citizenship. Such global protest movements constitute a check on nation states and put them under an obligation to 
respect human rights, as well as to refrain from exploiting or persecuting individuals within their borders. It creates, also, the conditions where all nations actions are monitored, and rendered accountable, at supra-national levels, and where each are encouraged to adjust their own regime to accord with international standards and principles that have been deemed important at this time. Although the Iraq war has set back the cause of constructive international relations by decades, undermining the role of the United Nations, and having a hugely detrimental affect on producing a viable global approach to humanitarian intervention, notwithstanding such setbacks, it is towards a stable and just international order that Foucauldian political economy strives.

\section{Acknowledgements}

This article was previously published in Anthony Green, Glenn Rikowski and Helen Raduntz (eds.), Renewing Dialogues in Marxism and Education: Openings. New York: Palgrave/Macmillan, pp. 151-182, March, 2008. The editors and publishers are thanked for its reproduction in this outlet.

\section{NOTES}

1. This introduction is based upon an editorial written for a special issue called "Marxist Futures" for the journal Policy Futures in Education (Peters, 2004).

2. References here and below except where otherwise indicated are from web site: http://www.marxists.org/archive/marx/works/1859/critique-pol-economy/ index/htm (accessed 12th Sept, 2005, transcribed by Tim Delaney.

3. The full title of Darwin's masterpiece is On the Origin of Species by Means of Natural Selection, or the Preservation of Favoured Races in the Struggle for Life available at http://www.literature.org/authors/darwin-charles/the-origin-of-species/ index.html (accessed 13th Sept., 2005).

4. While Marx did indeed send Darwin a copy of his famous work in second edition to Darwin in 1873 it remained uncut on his shelves and there is no evidence that he read it. It also seems likely that the source of the myth is a confusion over a letter by Darwin published in a Soviet newspaper in 1931 which does not mention Marx but declines the offer of a dedication. The letter concerned Edward Aveling's (Marx's son in law) The Students' Darwin (Wheen, 1999); see also http://www. evowiki.org/index.php/Darwin_and_Marx (accessed 13 Sept., 2005).

5. See also Bowles \& Gintis (2001), "Schooling in Capitalist America Revisited" at http://www.umass.edu/preferen/gintis/soced.pdf\#search=\%22Herbert\%20Gintis\% 2C\%20Schooling\%20in\%20Capitalist $\% 20$ America\%3A\%20Educational\%20Refor $\mathrm{m} \% 20$ and $\% 22$.

6. Political economy originally in the Greek had three related meanings: oikonomia meant the management of a household or family, politike meant pertaining to the state; and, ta oikonomika or economics, meant the art of household management. Thus political economy originally meant the management of the household of the 
State. It was used in this sense both by Jean-Jacques Rousseau and Adam Smith. Rousseau in "A Discourse on Political Economy" in 1755 defines political economy as "the government of the State for the common good." Rousseau says, "The word Economy, or OEconomy, is derived from oikos, a house, and nomos, law, and meant originally only the wise and legitimate government of the house for the common good of the whole family. The meaning of the term was then extended to the government of that great family, the State. To distinguish these two senses of the word, the latter is called general or political economy, and the former domestic or particular economy" (http://www.constitution.org/jjr/polecon.htm accessed 14 August 2005).

7. New political economy seeks to combine "the breadth of vision of the classical political economy of the 19th century with the analytical advances of twentiethcentury social science;" to overcome old distinctions and divisions of the past (agency/structure; state/market) to provide an integrated analysis that draws on a range of concepts and methodologies without favoring adherence to one particular school, method or theoretical approach. New political economy might draw on a range of theory: institutional-organizational approaches in economics; comparative theories of institutional and economic change in economics and economic history; structuration theory and strategic-relational theory in sociology; critical theories in international relations. This is drawn from the Editorial by Andrew Gamble, Anthony Payne, Michael Dietrich, Ankie Hoogvelt and Michael Kenny for the journal New Political Economy when it was established in 1996.

8. This paragraph is reformulated from the book by Mark Olssen (2006a), Michel Foucault: Materialism and Education, Boulder, Paradigm Publishers.

9. In his Résumé du cours for 1979 (in Foucault, 2004b: 323) Foucault indicates that the method he will adopt is based on Paul Veyne's nominalist history and in this respect he writes:
Et reprenant un certain nombre de choix de méthode déjà faits, j'ai essayé d'analyser le <<libéralisme〉>, non pas une théorie ni comme une idéologie, encore moins, bein entendu, comme une mannière pour la $<<$ société $\rangle>$ de $<<$ sel représenter $>>$; mais comme une pratique, c'est-à- dire comme une <<manière de faire $>>$ orientée vers objectifs et se régulant par une réflexion continue. Le libéralisme est à analyser alors comme principe et méthode de rationalisation de l'exercice de gouvern- ement-rationalisation qui obéit, et c'est là sa spécificité, à la règle interne de l'économie maximale.

10. The Foucault archives have been relocated from the IMEC (Institut Mémoires de l'Édition Contemporaine) Paris address (9, rue Bleue, F-75009 Paris) to Abbaye d'Ardenne (14280 Saint Germaine la Blanche-Herbe), email: bibliotheque@imecarchives.com. <<Il faut défender la société>>, a course Foucault delivered in 19751976, was translated into by David Macey as Society Must Be Defended was published in 2003 by Penguin (Foucault, 2003). While courses for 1977-78, 1978-79, as previously mentioned, and 1981-82 (<<L'Herméneutique de sujet $>>)$ have been recently published (in the Gallimand/Seuill series), courses for the years 1979-80, 1980-81, 1982-83, 1983-84 are still only available from the IMEC Foucault archive as recorded tapes. Some work has still to be translated. 
11. The governmentality literature has grown up around the journal Economy and Society, and includes the work of Cruickshank, Hindess, Hunter, Larner, Minson, O'Malley, Owen, and others, as well as those referred to above, most of who have published in Economy and Society (for aims and scope, and table of contents, see http://www.tandf.co.uk/journals/titles/03085147.asp).

12. See Olssen, Codd, O’Neill (2004: 167-171); Olssen, 2006: pp. 29-30, 108, Ch. 10. Also see "Why Foucault?" (Peters, 2004) where Peters discusses Foucault studies in the English-speaking world by reference to the work of Marshall, Olssen, Ball, Popkewitz \& Brennan, Besley, Baker, Middleton and myself. My work on Foucault's governmentality dates from Peters (1994), with additional work in 1996 (with Marshall), Peters (1996), Peters (1997), and Peters (2001a, b, c). For additional work on Foucault see Peters (2003a \& b), Peters (2005a \& b). A special issue of Educational Philosophy and Theory published a special issue in 2006 entitled "The Learning Society and Governmentality" edited by Masschelein, Bröckling, Simons and Pongratz.

13. As he writes in his Résumé du cours (in Foucault, 2004b: 323):

Le thème retenu était doc la <<biopolitique>>: j'entendais par là la manière don't on a essayé, depuis le XVIII siècle, de rationaliser les problèmes posés à la pratique gouvenrement par les phénomènes propres à une ensemble de vivants constitutes en population: santé, hygiene, natalitié, longévité, races...

14. The remainder of this section is reformulated and drawn from Olssen, Codd, O’Neill (2004) Education Policy: Globalisation, Citizenship, Democracy. London: Sage.

15. This is the process which Ritzer (2000) describes as the "McDonaldization of Society."

16. The reason usually given, but which in any case would be consistent with our statement here, is that Marx considered theoretical speculation of this sort unscientific, indeed, utopian, because economic and social conditions would themselves change in ways that were unpredictable.

17. See Deleuze's (1988) book called Spinoza: Practical Philosophy, where he articulates the theory of affects.

18. Types of affects might include desire, sadness or joy, as they did for Spinoza. However, the reader should entertain the possibility that Foucault would quite possibly object to this form of theorizing on the ground he eschewed normative theorizing of this sort. In extending Foucault in this way, it is thus in the spirit of the types of educational possibility and the types of normative theory that we are observing might "fit" with his Nietzschean approach. This seems to be a worthwhile way to extend Foucault if the possibilities of a Foucauldian radical political economy are to be developed.

19. The occasion for the statement cited here, published in Liberation in June 1884, was the announcement in Geneva of the creation of an international committee against piracy. 


\section{REFERENCES}

Barry, A., Osborne, T., and Rose, N. (eds.) (1996), Foucault and Political Reason:

Liberalism, Neo-liberalism and Rationalities of Government. London: UCL Press.

Bataille, G. (2004), On Nietzsche. London: Continuum.

Becker, G. (1964), Human Capital; A Theoretical and Empirical Analysis, With

Special Reference to Education. New York: National Bureau of Economic

Research/Columbia University Press.

Bennett, J. (1996), “'How is It, Then, That We Still Remain Barbarians?:' Foucault,

Schiller, and the Aestheticization of Ethics," Political Theory 24(4): 653-672.

Bowles, S., and Gintis, H. (1976), Schooling in Capitalist America: Educational

Reform and the Contradictions of Economic Life. New York: Basic Books.

Boyer, R. (1986), La Théorie de la régulastion: une analyse critique. Paris: La

Découverte.

Brier, S. (1999), in Roundtable on the Future of the Left, Socialism \& Democracy.

Broyer, S. (1996), "The Social Market Economy: Birth of an Economic Style."

Discussion Paper FS I 318, Social Science Research Center, Berlin.

Buchanan, J. (1991), Constitutional Economics. Oxford-Cambridge, MA: Blackwell.

Burchell, G. (1991), "Peculiar Interests: Civil Society and Governing 'The System of

Natural Liberty,"' in Burchell, G., Gordon, C., and Miller, P. (eds.), The Foucault

Effect: Studies in Governmentality. Chicago, IL: The University of Chicago Press.

Burchell, G. (1996), "Liberal Government and Techniques of the Self," in A. Barry,

T. Osborne, and N. Rose (eds.), Foucault and Political Reason. Chicago: University of Chicago Press, 19-36.

Burchell, G., Gordon, C., and Miller, P. (eds.) (1991), The Foucault Effect: Studies in Governmentality. Chicago, IL: University of Chicago Press and Harvester.

Callinicos, A. (2003), An Anti-capitalist Manifesto. Cambridge: Polity Press.

Carver, T. (1998), The Postmodern Marx. Manchester: Manchester University Press.

Curtis, B. (2002), "Foucault on Governmentality and Population: The Impossible

Discovery," Canadian Journal of Sociology 27(4): 505-35.

Day, R. B. (2002), "History, Reason and Hope: A Comparative Study of Kant, Hayek and Habermas," Humanitas XV(2): 4-24.

Dean, M. (1999), Governmentality: Power and Rule in Modern Society. London: Sage.

Deleuze, G. (1988), Spinoza: Practical Philosophy. San Francisco, CA: City Lights Books.

Derrida, J. (1994) Specters of Marx: The State of the Debt, the Work of Mourning, and the New International. Trans. Kamuf, Peggy with an introduction by Magnus, Bernd and Cullenberg, Stephen. New York-London: Routledge.

Desai, M. (2002), Marx's Revenge: The Resurgence of Capitalism and the Death of Statist Socialism. London: Verso.

Dosse, F. (1997), History of Structuralism Volume 2: The Sign Sets, 1967-present.

Trans. Glassman, Deborah. Minneapolis, MN-London: University of Minnesota Press.

Du Gay, Paul, Stuart Hall, Linda Janes, Hugh Mackay, and Keith Negus (1997),

Doing Cultural Studies: The Story of the Sony Walkman. London: Sage.

Featherstone, Mike (1991), Consumer Culture \& Postmodernism. London: Sage. 
Ferguson, A. (1996), An Essay on the History of Civil Society 1767. Forbes, Duncan (ed.). Edinburgh: Edinburgh University Press.

Foucault, M. (1972), The Archaeology of Knowledge. Trans. Sheridan, A. London: Tavistock.

Foucault, M. (1977), Discipline and Punish: The Birth of the Prison. Trans. Sheridan, A. London: Penguin, 195-228.

Foucault, M. (1977a), Language, Counter-Memory, Practice: Selected Essays and Interviews. Bouchard, Donald (ed.). Oxford: Blackwell, 204-217.

Foucault, M. (1977b), "A Preface to Transgression," in Bouchard, D. (ed.), Language, Counter-Memory, Practice: Selected Essays and Interviews. Trans. D. Bouchard \& S. Simon. Ithaca, NY: Cornell University Press, 29-52.

Foucault, M. (1978), "Politics and the Study of Discourse," trans. Gordon, C., Ideology and Consciousness 3(Spring): 7-26.

Foucault, M. (1980), "Truth and Power," in Gordon, C. (ed.), Power/Knowledge: Selected Interviews and Other Writings, 1972-1977. Brighton: Harvester Press.

Foucault, M. (1980a), "Prison Talk," in Gordon, C. (ed.), Power/Knowledge: Selected Interviews and Other Writings, 1972-1977. Brighton: Harvester Press.

Foucault, M. (1982), "The Subject and Power," in Dreyfus, Hubert and Rabinow, Paul (eds.), Michel Foucault: Beyond Structuralism and Hermeneutics. Chicago, IL: University of Chicago.

Foucault, M. (1984), "What Is Enlightenment?," in Rabinow, Paul (ed.), The Foucault Reader. New York: Pantheon.

Foucault, M. (1984a), "Politics and Ethics: An Interview," in Rabinow, Paul (ed.), The Foucault Reader. New York: Pantheon.

Foucault, M. (1985), The Use of Pleasure: The History of Sexuality. Volume 2. Trans. Robert Hurley. New York: Pantheon.

Foucault, M. (1986), "Kant on Enlightenment and Revolution," trans. Gordon, C., Economy and Society 15(1): 88-96.

Foucault, M. (1989), "Resume des cours 1970-1982, Paris: conferencs, essais et lecons du Collège de France." Paris: Julliard.

Foucault, M. (1989a), "An Aesthetics of Existence," in Lotringer, Sylverer (ed.), Foucault Live. New York: Semiotext(e).

Foucault, M. (1997), "The Ethics of the Concern for the Self as a Practice of Freedom," in Rabinow, Paul (ed.), Ethics: Subjectivity and Truth. Essential Works of Michel Foucault 1954-1984. Volume 1. London: Penguin.

Foucault, M. (1998), "Structuralism and Poststructuralism," in Faubion, James D. (ed.), Aesthetics, Method, Epistemology. Essential Works of Michel Foucault, 1954-1984. Volume 2. New York: The New Press.

Foucault, M. (2001), "Governmentality," in Faubion, James D. (ed.), Michel Foucault: Power. The Essential Works of Michel Foucault, 1954-1984. Volume 3. London: Allen Lane \& The Penguin Press, 201-222.

Foucault, M. (2001a), "Interview with Michel Foucault," in Faubion, James D. (ed.), Michel Foucault: Power. The Essential Works of Michel Foucault, 1954-1984. Volume 3. London: Allen Lane \& The Penguin Press. 
Foucault, M. (2001b), "Confronting Governments: Human Rights," in Faubion, James D. (ed.), Michel Foucault: Power. The Essential Works of Michel Foucault, 1954-1984. Volume 3. London: Allen Lane \& The Penguin Press.

Foucault, M. (2004a), Sécurité, Territoire, Population: Cours au collège de France (1977-1978). Francois Ewald, Alessandro Fontana, and Michel Senellart (eds.). Paris: Gallimard and Seuil.

Foucault, M. (2004b), Naissance de la biopolitique: Cours au collège de France (1978-1979). Francois Ewald, Alessandro Fontana, and Michel Senellart (eds.). Paris: Gallimard and Seuil.

Giddens, A. (1994), Beyond Left and Right: The Future of Radical Politics. Cambridge: Polity Press.

Gordon, C. (2001), "Introduction," in Faubion, James D. (ed.), Michel Foucault: Power. The Essential Works of Michel Foucault, 1954-1984. Volume 3. London: Allen Lane \& The Penguin Press.

Gray, J. N. (1982), "F. A. Hayek and the Rebirth of Classical Liberalism," Literature of Liberty v(4) Winter, accessed at http://www.econlib.org/library/Essays/ LtrLbrty/gryHRC1.html

Hayek, F. A. (1960), The Constitution of Liberty. Chicago, IL: University of Chicago Press.

Jameson, F. (1991), Postmodernism, or the Cultural Logic of Late Capitalism. London: Verso.

Joerges, C., and Rödl, F. (2004), “'Social Market Economy’ as Europe’s Social Model?," Working Paper LAW 8, European University Institute (Florence), accessed at www.iut.it.

Lemke, T. (2001), “'The Birth of Biopolitics:' Michel Foucault's Lectures at the College de France on Neo-liberal Governmentality," Economy and Society 30(2): 190-207.

Lipietz, A. (1983), Le monde enchanté: De la valeur à l'envol inflationniste. Paris: La Découverte.

Lipietz, A. (1995), Green Hopes: The Future of Political Ecology. Cambridge: Polity Press.

Marx, K., and Engels, F. (1965), Selected Correspondence. Moscow: Foreign Languages Publishing House.

Marx, K. (1971), A Contribution to the Critique of Political Economy. Introduction by Maurice Dobb. London: Lawrence and Wishart.

Miller, Daniel (1995), Acknowledging Consumption: A Review of New Studies. London and New York: Routledge.

Miller, Daniel (1997), "Consumption and Its Consequences," in Makay, H. (ed.), Consumption and Everyday Life. London: Sage.

Miller, P., and Rose, N. (1990), "Governing Economic Life," Economy and Society 19(1): 1-31 and 19(3): 49-64.

Olssen, M., Codd, J., and O’Neill, A-M. (2004), Education Policy: Globalisation, Citizenship, Democracy. London: Sage.

Olssen, M. (2006a), Michel Foucault: Materialism and Education, Boulder, CO: Paradigm Publishers. 
Olssen, M. (2006b), "Foucault and the Imperatives of Education: Critique and Self Creation in a Non-Foundational World," Studies in Philosophy and Education 25(3): 191-217.

Olssen, M. (2006c), "Foucault, Educational Research and the Issue of Autonomy," in Smeyers, Paul and Peters, Michael A. (eds.), Postfoundationalist Themes in the Philosophy of Education. Oxford: Blackwell, 231-263.

Olssen, Mark (2006d), "Understanding the Mechanisms of Neoliberal Control: Lifelong Learning, Flexibility and Knowledge Capitalism," International Journal of Lifelong Education 25(3): 213-230.

Olssen, M. (2006e), "Totalitarianism and the Repressed Utopia of the Present," in Peters, Michael and Freeman Moir, John (eds.), Edutopias: New Utopian Thinking in Education. Dordtrecht: Sense Publishers, 99-124.

Olssen, M. (2006f), "Invoking Democracy: Foucault's Conception (with Insights from Hobbbes)', in Peters, Michael and Belsey, Tina (eds.), Why Foucault. New York: Peter Lang, 231-261.

Olssen, M. (2005), "Foucault and Marx: Re-writing the History of Historical Materialism," Policy Futures in Education 2(3): 453-480.

Olssen, M. (2003), "Structuralism, Post-Structuralism, Neo-Liberalism: Assessing Foucault's Legacy," Journal of Education Policy 18(2): 189-202.

Olssen, M. (2004), "The School as the Microscope of Conduct: On Doing Foucauldian Research in Education," in J. Marshall (ed.), Poststructuralism and Education. Dordrecht: Kluwer Academic Publishers, 57-84.

Osborne, D., and Gaebler, T. (1992), Reinventing Government: How the Entrepreneurial Spirit is Transforming the Public Sector, from Schoolhouse to Statehouse, City Hall to the Pentagon. Reading, MA: Addison-Wesley.

Peters, M. A., and Marshall, J. (1996), Individualism and Community: Education and Social Policy in the Postmodern Condition. London: Falmer Press.

Peters, M. A. (1994), "Governmentalidade Neoliberal e Educacao," in Tadeu da Silva, T. (ed.), O Sujeito Educacao, Estudos Foucaulianos. Rio de Janeiro: Editora Vozes.

Peters, M. A. (1996), Poststructuralism, Politics and Education. Westport, CTLondon: Bergin and Garvey.

Peters, M. A. (1997), "Neoliberalism, Welfare Dependency and the Moral Construction of Poverty in New Zealand," New Zealand Journal of Sociology 12(1): 134.

Peters, M. A. (2001a), "Foucault, Neoliberalism and the Governance of Welfare," in Poststructuralism, Marxism, and Neoliberalism: Between Theory and Politics. Lanham-Oxford: Rowman \& Littlefield.

Peters, M. A. (2001b), "Education, Enterprise Culture and the Entrepreneurial Self: A Foucauldian Perspective," Journal of Educational Enquiry 2(2): 58-71.

Peters, M. A. (2001c), "Foucault and Governmentality: Understanding the Neoliberal Paradigm of Education Policy," The School Field XII(5/6): 59-80.

Peters, M. A. (2003a), "Truth-Telling as an Educational Practice of the Self: Foucault, Parrhesia and the Ethics of Subjectivity," Oxford Review of Education 29(2): 207-223. 
Peters, M. A. (2003b), "Educational Research, 'Games of Truth' and the Ethics of Subjectivity" Symposium: Michael A. Peters, Tina Besley and Clare Caddell, Ethical Educational Research: Practices of The Self, BERA.

Peters, M. A. (2003c), Keynote address: "Why Foucault? New Directions in AngloAmerican Educational Research," Conference After Foucault: Perspectives of the Analysis of Discourse and Power in Education, 29-31 October, Dortmund: University of Dortmund. Also in Pongratz, L. et al. (eds.) (2004), Nach Foucault. Diskurs- und machtanalytische Perspectiven der Pädagogi. Wiesbaden: VS Verlag Für Sozialwissenschaften.

Peters, M. A. (2004), Editorial: "Marxist Futures: Knowledge Socialism and the Academy," Policy Futures in Education 2(3\&4): 435-438.

Peters, M. A. (2005a), "Foucault, Counselling and the Aesthetics of Existence," in British Journal of Counselling and Guidance 33(3): 383-396.

Peters, M. A. (2005b), "The New Prudentialism in Education: Actuarial Rationality and the Entrepreneurial Self," Educational Theory 55(2): 123-137.

Peters, M. A. (2005c), "Citizen-Consumers, Social Markets and the Reform of Public Services," Policy Futures in Education 2(3/4): 621-632.

Pignatelli, F. (1993), "Dangers, Possibilities: Ethico-Political Choices in the Work of Michel Foucault," accessed at http://www.ed.uiuc.edu/EPS/PES-Yearbook/93_ docs/PIGNATEL.HTM

Poster, M. (1984), Foucault, Marxism, History: Mode of Production vs Mode of Information. Cambridge: Polity Press.

Ritzer, G. (2000), The McDonaldization of Society. Thousand Oaks, CA: Pine Forge Press.

Rose, N. (1999), Powers of Liberty. Cambridge: Cambridge University Press.

Schatzki, T., Knorr Cetiona, K., and Von Savigny, E. (eds.) (2001), The Practice Turn in Contemporary Theory. London-New York: Routledge.

Schrift, A. D. (1995), Nietzsche's French Legacy: A Genealogy of Poststructuralism. New York-London: Routledge.

Thompson, K. (1986), Beliefs and Ideologies. Chichester: Ellis Harwood.

Vanberg, V. (2004), "The Freiburg School: Walter Eucken and Ordoliberalism," Discussion Papers on Constitutional Economics, Freiburg, accessed at http:// opus.zbw-kiel.de/volltexte/2004/2324/pdf/04_11bw.pdf.

Weber, M. (1921), Economy and Society. Totowa, NJ: Bedminster.

Williams, R. (1980), Problems in Materialism and Culture. London: Verso.

Witt, U. (2002), “Germany's 'Social Market Economy:' Between Social Ethos and Rent Seeking," The Independent Review IV(3): 365-375.

Willis, P. (1977/1981), Learning to Labour. How Working Class Kids Get Working

Class Jobs. Farnborough, Hants: Saxon House. 